Situs Jurnal : $\underline{\text { http://ejournal.stiepancasetia.ac.id/index.php/jieb }}$

Jilid 6 Nomor 2 Juli 2020

Hal $192-201$

\title{
ANALISIS PENGARUH PEMAHAMAN AKUNTANSI DAN KEAKTIFAN MAHASISWA TERHADAP PENYUSUNAN LAPORAN KEUANGAN SESUAI SAK KASUS PADA MAHASISWA JURUSAN AKUNTANSI STIE PANCASETIA
}

\author{
Imawati Yousida*, Lina Kristanti*, Tina Lestari*
}

\begin{abstract}
This research aims to analyze influence understanding of accounting and student activeness towards the preparation of financial statement in accordance with The Financial Accounting Standards: case study in accounting department students STIE Pancasetia.The research method used quantitative with analytical techniques used are multiple linear regression. The population and sample used were fifty-seven seventh of students majoring in accounting.The results shows understanding of accounting and student activity simultaneously and partially have a significant effect on the preparation of financial statements in accordance with The Financial accounting standards. While the dominant variable influences the understanding of accounting.Understanding of accounting as the basic of basic accounting knowledge in the process of preparing financial reporting. So the advice given to the object of the research is expected to develop the level of understanding of students by developing learning that is more varied and consistent, especially in accounting practices, the completion of case studies related to the preparation of financial reports in accordance with financial accounting standards and for students to be able to increase their activity in the learning process such as actively asking questions, issuing opinions and sharing experiences related to accounting. As well as independent practice and critical thinking towards accounting developments in the future.
\end{abstract}

Keyword : Understanding of Accounting, Student Activity, Preparation of Financial Statements in Accordance, Financial Accounting Standards.

\section{PENDAHULUAN}

Perkembangan ilmu pengetahuan seiring dengan perkembangan teknologi, dalam perkembangan diperlukan sumber daya manusia yang berkualitas. Salah satu upaya pendidikan untuk berperan serta dalam perkembangan sumber daya manusia dengan meningkatkan keampuan mahasiswa. Mahasiswa dituntut tidak hanya mempunyai kemampuan akademik yang memadai namun keterampilan teknis serta mental dan kepribadian yang baik, sehingga mampu mengahadapi perkembangan jaman dan berperan serta dalam pembangunan.
Keberhasilan mahasiswa dapat dipengaruhi beberapa faktor seperti pemahaman, dan keaktifan belajar. Paham menurut Kamus Umum Bahasa Indonesia (Poerwadarminta: 2006) mempunyai pengertian pandai dan mengerti benar, sedangkan pemahaman adalah proses, cara perbuatan memahami atau memahamkan. Ini berarti bahwa orang yang memiliki pemahaman akuntansi adalah orang yang pandai dan mengerti benar tentang akuntansi. Seseorang dikatakan paham terhadap akuntansi adalah mengerti dan pandai bagaimana proses akuntansi itu dilakukan sampai menjadi suatu laporan keuangan dengan berpedoman pada prinsip dan standar 
penyusunan laporan keuangan. Untuk dapat memahami pembelajaran dan segala kegiatan yang bertujuan pengembangan kemampuan, mahasiswa wajib berperan serta aktif. Keaktifan mahasiswa merupakan hal yang perlu diperhatikan, sehingga proses pembelajaran yang ditempuh memperoleh hasil yang optimal, sehingga nantinya dapat diperoleh lulusan yang berkualitas. Peningkatan kualitas pendidikan akuntansi sulit dilakukan jika pendidikan yang selama ini berjalan belum dievaluasi. Evaluasi tersebut dapat berasal dari Badan Akreditasi Nasional, pengguna lulusan ataupun mahasiswa sebagai peserta. Evaluasi terhadap pendidikan akuntansi di dalam negeri telah dilakukan antara lain oleh Hutapea (1998) Hasil penelitian menunjukkan bahwa efektif atau tidaknya perkuliahan mempengaruhi banyaknya materi yang diserap dan dipahami mahasiswa dan proses perkuliahan yang efektif, diharapkan apa yang seharusnya diketahui oleh mahasiswa benar- benar tersampaikan dan diterima dengan baik oleh mahasiswa serta dapat meningkatkan pengetahuan dan ketrampilan yang dibutuhkannya.Tingkat pengetahuan mahasiswa ternyata berkorelasi positif terhadap prestasinya walaupun secara statistis tidak signifikan. Hal ini disebabkan tingkat pengetahuan mahasiswa bukan satu-satunya variabel dalam menentukan nilai akhir. Variabel lain yang berpengaruh misalnya frekuensi kehadiran, tugas-tugas dan keaktifan di kelas. Penelitian juga menunjukkan bahwa metode diskusi menjadi metode yang paling efektif dalam mengajarkan mata kuliah akuntansi. Kelaskelas yang diskusinya lebih dominan memiliki nilai efektivitas total yang lebih tinggi dibandingkan kelas perkuliahan biasa.

Menurut Usman (2002:24), "keaktifan adalah keterlibatan intelektual emosional siswa dalam kegitan belajar mengajar yang bersangkutan, asimilasi dan akomodasi kognitif dalam pencapaian pengetahuan, perbutan serta pengalaman langsung terhadap balikannya (feed back) dalam pembentukan sikap". Pemahaman dan keaktifan mahasiswa yang memuaskan merupakan bentuk keberhasilan yang dapat dilihat dari nilai-nilai yang diperoleh mahasiswa mulai dari awal perkuliahaan sampai akhir periode perkuliahan.

Akuntansi dapat dipandang sebagai bidang pengetahuan teknologi yang menyusut pada berbagai ilmu pengetahuan dan membentuk seperangkat pengetahuan akuntansi. Akibat perkembangan ekonomi, perdagangan luar negeri, komunikasi, dan teknologi maka pemanfaatan teknologi informasi akuntansi menjadi semakin luas dan canggih dalam berbagai bidang dan organisasi.

Financial Accounting Standards Board ini mengganti Accounting

Board (APB). Financial

Principle

Standards Board merupakan badan otoritatif yang dibangun pada tahun 1959 oleh American Institute of Certified Public Acoountants (AICPA). Menurut FASB, akuntansi adalah kegiatan jasa yang berfungsi menyediakan informasi kuantitatif yang kemudian digunakan untuk pengambilan keputusan ekonomi. Badan ini menerbitkan pernyataan dan prinsip-prinsip akuntansi yang dipakai di seluruh dunia. Warren menyimpulkan dan mendefinisi akuntansi sebagai suatu informasi yang menghasilkan suatu laporan yang dibutuhkan oleh pihak-pihak yang memiliki kepentingan terhadap suatu aktifitas ekonomi dan kondisi suatu perusahaan. Penyusunan laporan keuangan Menurut Weni, Budiyono dan Sarno (2007: 115) bahwa mata pelajaran akuntansi dapat diartikan sebagai mata pelajaran yang mempelajari tentang proses pengidentifikasian, pengukuran, pencatatan, dan pelaporan informasi akuntansi yang berfungsi dalam membantu dalam pengambilan keputusan bagi pihakpihak yang memerlukan. Selain itu juga pengertian akuntansi bergantung dari sudut mana kita melihatnya. Menurut Ridho (2014), yaitu (a). Dipandang dari sudut fungsinya , (b). Dipandang dari sudut kegiatannya.

Dunia usaha saat ini mendorong kebutuhan tenaga kerja yang mampu menyusun laporan keuangan. Untuk menghasilkan 
laporan keuangan yang dapat diandalkan diperlukan pemahaman yang benar dalam penyusunan laporan keuangan. Penyusunan laporan keuangan di Indonesia harus sesuai dengan Standar Akuntansi Keuangan (SAK). Untuk memperoleh suatu pengetahuan terhadap teori akuntansi yang mendasar maka diperlukan pengetahuan akan dasar-dasar akuntansi agar pengetahuan tersebut dapat dijadikan pegangan semua praktik akuntansi. Selain pemahaman akuntansi, pe-manfaatan teknologi informasi dibutuhkan sumber daya manusia yang kompeten untuk menghasilkan sebuah laporan keuangan yang berkualitas. Banyaknya pengetahuan akuntansi yang didapatkan dari pendidikan menengah akan memudahkan mahasiswa jurusan akuntansi untuk memahami mata kuliah akuntansi. Tanpa latar belakang pendidikan mereka akan kesulitan dalam memahami akuntansi, selain itu proses belajar mengajar juga sangat terkait dengan keaktifan belajar mahasiswanya, dimana keaktifan belajar mendorong keberhasilan untuk lebih cepat memahami. Masalah yang sering muncul adalah keaktifan mahasiswa saat ini cenderung rendah seperti kebanyakan bermain, belajar tidak teratur, daya tahan belajar rendah, dan belajar hanya pada saat menjelang ujian. Hal inilah yang menjadi kesulitan untuk dapat memahami penyusunan laporan keuangan sesuai standar akuntansi keuangan dengan baik. Berdasarkan uraian, penulis tertarik untuk mengadakan penelitian dengan mengambil judul "Analisis Pengaruh Pemahaman Akuntansi dan Keaktifan Mahasiswa Terhadap Penyusunan Laporan Keuangan Sesuai Standar Akuntasi keuangan".

\section{LANDASAN TEORI}

\section{Pemahaman Akuntansi}

Menurut Kimmel et al. (2011), akuntansi adalah sistem informasi yang mengidentifikasi, mencatat, dan mengkomunikasikan kejadian ekonomis suatuorganisasi kepada pihak-pihak yang berkepentingan. Dari definisi ini dapat dipahami bahwa akuntansi adalah proses mencatat dan melaporkan transaksi keuangan yang terjadi dalam suatu perusahaan kepada para penggunanya dalam bentuk laporan keuangan. Pengguna laporan keuangan terdiri dari investor, karyawan, pemberi pinjaman, pemasok dan kreditor usaha lainnya, pelanggan, pemerintah, dan masyarakat (Ikatan Akuntan Indonesia 2009).

Akuntansi adalah seni daripada pencatatan, penggolongan dan peringkasan pada peristiwa-peristiwa dan kejadian-kejadian yang setidak-tidaknya sebagian bersifat keuangan dengan cara yang setepattepatnya dan dengan petunjuk atau dinyatakan dalam uang, serta penafsiran terhadap hal-hal yang timbul daripadanya (Munawir, 2004). Dari defenisi akuntansi tersebut di ketahui bahwa peringkasan dalam hal ini dimaksudkan adalah pelaporan dari peristiwa-peristiwa keuangan perusahaan yang dapat diartikan sebagai laporan keuangan. Jadi laporan keuangan menurut Myer dalam (Munawir, 2004) adalah : Dua daftar yang disusun oleh Akuntan pada akhir periode untuk suatu perusahaan. Kedua daftar itu adalah daftar Neraca atau Daftar Pendapatan atau Daftar Rugi Laba. Pada waktu akhirakhir ini sudah menjadi kebiasaan bagi perseroanperseroan untuk menambah daftar ketiga yaitu Daftar Surplus atau Daftar Laba yang tidak dibagikan/laba yang ditahan (Munawir, 2004).

Dengan telah ditetapkan salah satu bentuk laporan keuangan, maka perusahaan harus konsisten melaksanakannya agar laporan keuangan tersebut dapat dipedomani dengan baik serta untuk menghindari anggapan-anggapan yang kurang baik terhadap perusahaan. Dengan demikian laporan keuangan tersebut dapat dinilai serta diperbandingkan dengan periode periode sebelumnya. Konsep dasar pemahaman akuntansi menurut (Munawir, 2004) terdiri dari tiga bagian utama yaitu aktiva, hutang dan modal. Aktiva merepresentasikan kekayaankekayaan yang dimiliki oleh entitas perusahaan, baik yang berwujud maupun tidak berwujud. Hutang 
dan modal, yang sering dikenal sebagai pasiva, menunjukkan sumber pendanaan bagi operasi perusahaan. Sumber pendanaan ini dapat berupa pinjaman dari pihak kreditur maupun penyertaan modal dari pemilik perusahaan.

Menurut Munawir (2007:5), pengertian akuntansi sebagai berikut: "Akuntansi adalah seni dari pencatatan, penggolongan, dan peringkasan dari pada peristiwaperistiwa dan kejadian-kejadian yang setidak-tidaknya sebagian bersifat keuangan dengan cara yang setepattepatnya dan dengan petunjuk atau dinyatakan dalam uang, serta penafsiran terhadap hal-hal yang timbul dari padanya". Definisi ini mengandung beberapa pengertian, yaitu: (1). Akuntansi merupakan proses yang terdiri dari identifikasi, pengukuran dan pelaporan informasi ekonomi. (2). Informasi ekonomi yang dihasilkan oleh akuntansi diharapkan beguna dalam penilaian dan pengambilan keputusan mengenai kesatuan usaha yang bersangkutan.

Menurut Suwardjono (2005) pengetahuan akuntansi dapat dipandang dari dua sisi pengertian yaitu sebagai pengetahuan profesi (keahlian) yang dipraktekkan di dunia nyata dan sekaligus sebagai suatu disiplin pengetahuan yang diajarkan di perguruan tinggi. Akuntansi sebagai objek pengetahuan di perguruan tinggi, akademisi memandang akuntansi sebagai dua bidang kajian yaitu bidang praktek dan teori. Bidang praktek berkepentingan dengan masalah bagaimana praktek dijalankan sesuai dengan prinsip akuntansi. Bidang teori berkepentingan dengan penjelasan, deskripsi, dan argumen yang dianggap melandasi praktek akuntansi yang semuanya dicakup dalam suatu pengetahuan yang disebut teori akuntansi.

Pembelajaran akuntansi berfungsi untuk mengembangkan pengetahuan, keterampilan, sikap rasional, teliti, jujur, dan bertanggungjawab melalui prosedur pencatatan, pengelompokan, pengikhtisaran transaksi keuangan, penyusunan laporan keuangan dan penafsiran perusahaan berdasarkan Standar
Akuntansi Keuangan. Salah satu materi mata pelajaran akuntansi pada mata kuliah Dasar Akuntansi adalah jurnal penyesuaian pada perusahaan dagang, dimana materi ini merupakan bagian dari siklus akuntansi perusahaan dagang yang memuat semua jurnal yang digunakan untuk menyesuaikan posisi masing-masing akun sehingga sesuai dengan posisinya pada tanggal laporan (Sofyan, 2004:22). Pembelajaran akuntansi dengan menggunakan metode konvensional umumnya lebih didominasi dengan kegiatan ceramah dan komunikasi lebih cenderung satu arah, sehingga mahasiswa menjadi kurang aktif. Metode ini lebih bersifat monoton dan membosankan bagi mahasiswa. Dalam banyak hal, dengan menggunakan metode konvensional bahkan dosen menghabiskan seluruh waktu perkuliahan untuk memaparkan materi, karena memang tuntutan muatan materi yang perlu disampaikan luas dan mendalam. Kondisi demikian tentu bukan merupakan langkah terbaik, sehingga perlu dicari alternatif yang inovatif.

Pemahaman adalah kemampuan seseorang untuk mengerti atau memahami sesuatu setelah sesuatu itu diketahui dan diingat. Seorang peserta didik dikatakan memahami suatu mata pelajaran apabila ia dapat memberikan penjelasan atau memberi uraian yang lebih rinci tentang hal yang telah dipelajari dengan menggunakan katakatanya sendiri. Pemahaman juga merupakan jenjang kemampuan berfikir yang setingkat lebih tinggi dari ingatan atau hafalan. Tingkat pemahaman akuntansi mahasiswa dinyatakan dengan seberapa mengerti seorang mahasiswa terhadap apa yang sudah dipelajari yang dalam konteks mengacu pada mata kuliah-mata kuliah akuntansi. Mahasiswa dapat dikatakan menguasai atau memahami akuntansi apabila ilmu akuntansi yang sudah di perolehnya selama ini dapat diterapkan dalam kehidupannya bermasyarakat atau dengan kata lain dapat dipraktekkan didunia kerja. Pendidikan akuntansi setidaknya harus dapat mempersiapkan peserta didik untuk memulai dan 
mengembangkan keanekaragaman karir profesional dalam bidang Akuntansi .

\section{Keaktifan Mahasiswa}

Keaktifan belajar siswa menurut Sudjana (2010: 20) adalah "Proses kegiatan belajar mengajar yang subjek didiknya terlibat intelektual dan emosional sehingga betulbetul berperan dan perpartisispasi aktif dalam melakukan kegiatan belajar". Dari pengertian ini menunjukan bahwa cara belajar siswa aktif menempatkan siswa sebagai inti dalam kegiatan belajar mengajar siswa disini dipandang sebagai objek dan sebagai subjek. Menurut teori kognitif, belajar menunjukan adanya jiwa yang sangat aktif, jiwa mengolah informasi yang kita terima, tidak sekedar menyimpannya saja tanpa mengadakan transformasi, namun jika mengolah dan melakukan informasi transformasi informasi yang kita terima (Dimyati dan Mudjiono, 2006: 45). Kata aktif diartikan sebagai giat, rajin, dalam berusaha dan bekerja. Dalam hal ini adalah kegiatan atau kesibukan peserta didik dalam kegiatan belajar mengajar di sekolah serta ikut berpartisipasi dalam setiap tahapan pembelajaran yang menunjang keberhasilan siswa belajar. Adapun karakteristik siswa aktif yang dikemukakan oleh Sudjana dan Arifin (2008:23) yaitu: (1) Keinginan, keberanian menampilkan minat, kebutuhan dan permasalahanya. (2) Keinginan dan keberanian serta kesempatan untuk berpartisipasi dalam kegiatan persiapan, proses dan kelanjutan belajar. (3) Penampilan berbagai usaha atau keaktifan belajar dalam menjalani dan menyelesaikan kegiatan belajar mengajar sampai mecapai keberhasilannya. (4) Kebebasan dan keleluasaan melakukan hal tersebut di atas tanpa tekanan guru atau pihak lainnya (kemandirian belajar).

Dengan demikian berdasarkan paparan di atas dapat disimpulkan karakteristik siswa aktif yaitu yang memiliki keberanian dalam menampilkan minat, berpartisipasi dalam kegiatan persiapan, memiliki keaktifan belajar dalam menjalani dan menyelesaikan kegiatan belajar serta memiliki kemandirian dalam belajar untuk mencapai keberhasilan dalam belajar.

Aktivitas siswa dalam proses belajar menurut Sudjana (2010:61) mengemukakaan bahwa kriteria aktivitas belajar siswa dapat dilihat dalam berbgaia hal antara lain:

(1) Turut serta dalam melaksanakan tugas belajarnya, (2) Terlibat dalam pemecahan siswa, (3) Bertanya pada siswa lain/guru tentang masalah yang belum dipahami, (4) Berusaha mencari informasi yang diperlukan berkaitan dengan pemecahan masalah yang dipelajarinya, (5) Melaksanakan kerja kelompok sesuai dengan petunjuk guru, (6) Melatih diri dalam memecahkan masalah bersama kelompok, (7) Kesempatan menggunakan atau menerapkan apa yang telah diperolehnya dalam menyelesaikan tugas/persoalan yang di hadapi.

\section{Laporan keuangan Menurut Standar Akuntansi Keuangan (SAK)}

Menurut Kasmir (2013:7), financial statement adalah suatu laporan yang menunjukkan kondisi keuangan perusahaan saat ini atau periode berikutnya.

PSAK 1 Tentang Penyajian Laporan keuangan telah disahkan oleh Dewan Standar Akuntansi Keuangan pada tanggal 19 Desember 2013. PSAK ini merevisi PSAK1 tentang Penyajian Laporan keuangan yang telah diterbitkan pada tanggal 15 Desember 2009. Pernyataan ini tidak wajib diterapkan untuk unsur yang tidak material. Pernyataan ini mengatur persyaratan penyajian laporan keuangan, struktur laporan keuangan, dan persyaratan minimal isi laporan keuangan. Entitas menerapkan Pernyataan ini dalam penyusunan dan penyajian laporan keuangan bertujuan umum sesuai dengan SAK. Pernyataan ini tidak berlaku bagi penyusunan dan penyajian laporan keuangan entitas syariah. Komponen laporan keuangan lengkap terdiri dari: (a) laporan posisi keuangan pada akhir periode; (b) laporan laba rugi dan penghasilan komprehensif lain selama periode; (c) laporan perubahan ekuitas selama periode; 
(d). laporan arus kas selama periode; (e) catatan atas laporan keuangan, berisi ringkasan kebijakan akuntansi yang signifikan dan informasi penjelasan lain; (e.a) informasi komparatif mengenai periode terdekat sebelumnya sebagaimana ditentukan dalam paragraf 38 dan 38A; dan (f) laporan posisi keuangan pada awal periode terdekat sebelumnya ketika entitas menerapkan suatu kebijakan akuntansi secara retrospektif atau membuat penyajian kembali pos-pos laporan keuangan, atau ketika entitas mereklasifikasi pos-pos. dalam laporan keuangannya sesuai dengan paragraf 40A-40D.

Entitas menerapkan Pernyataan ini untuk periode tahun buku yang dimulai pada atau setelah tanggal 1 Januari 2015. Entitas. menerapkan penyesuaian paragraf 128 dan secara prospektif untuk periode tahun buku yang dimulai pada atau setelah tanggal 1 Januari 2015.

\section{Standar Akuntansi Keuangan (SAK)}

Standar Akuntansi Keuangan (SAK) adalah Pernyataan Standar Akuntansi Keuangan (PSAK) dan Interpretasi Standar Akuntansi Keuangan (ISAK) yang diterbitkan oleh Dewan Standar Ikatan Akuntan Indonesia (DSAK IAI) dan Dewan Standar Syariah Ikatan Akuntan Indonesia (DSAS IAI) serta peraturan regulator pasar modal untuk entitas yang berada di bawah pengawasannya. Efektif 1 Januari 2015 yang berlaku di Indonesia secara garis besar akan konvergen dengan International Financial Reporting Standards (IFRS)

$\mathrm{Y}=\mathrm{a}+\mathrm{b}_{1} \mathrm{X}_{1}+\mathrm{b}_{2} \mathrm{X}_{2}+\varepsilon$

yang berlaku efektif 1 Januari 2014. DSAK IAI telah berhasil meminimalkan perbedaan antara kedua standar, dari tiga tahun di 1 januari 2012 menjadi satu tahun di 1 Januari 2015. Ini merupakan suatu bentuk komitmen Indonesia melalui DSAK IAI dalam memainkan perannya selaku satu-satunya anggota G20 di kawasan Asia Tenggara.

Kerangka konseptual dari penelitian ini adalah :

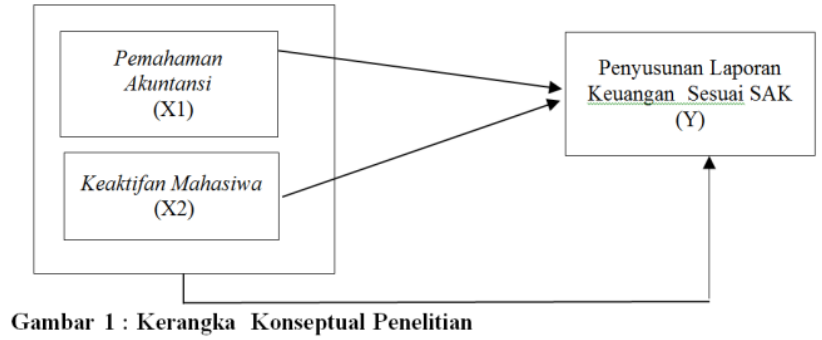

Berdasarkan uraian kerangka konseptual tersebut, maka peneliti mengajukan beberapa hipotesis dalam penelitian ini sebagai berikut :

Diduga Pemahaman Akuntansi dan Keaktifan Mahasiswa berpengaruh secara simultan terhadap Penyusunan Laporan Keuangan Sesuai Standar Akuntansi Keuangan.

Diduga Keaktifan Mahasiswa berpengaruh secara parsial terhadap Penyusunan Laporan Keuangan Sesuai Standar Akuntansi Keuangan

H3: Diduga Pemahaman Akuntansi paling dominan berpengaruh terhadap Penyusunan Laporan Keuangan Sesuai Standar Akuntansi Keuangan

\section{METODOLOGI PENELITIAN}

Jenis penelitian ini adalah penelitian kuantitatif, dengan populasi dan sample sebanyak 57 orang mahasiswa jurusan akuntani semester VII (tujuh). Analisis data dilakukan dengan batuan program komputer yaitu SPSS. Dimana alat analisis yang digunakan yaitu analisis regresi linier berganda. Rumus regresi yang digunakan adalah:

Keterangan

$\mathrm{Y}=$ Penyusunan Laporan Keuangan Sesuai

$$
\begin{aligned}
& \text { Standar Akuntansi Keuangan } \\
& \mathrm{a}=\text { Konstanta } \\
& \mathrm{X} 1=\text { Pemahaman Akuntansi } \\
& \mathrm{X} 2=\text { Keaktifan Mahasiswa } \\
& \mathrm{b}_{1}=\text { Koefisien Regresi Berganda } \\
& \mathrm{b}_{2}=\text { Koefisien Regresi Berganda } \\
& \varepsilon=\text { Standar error }
\end{aligned}
$$

Penelitian ini menghubungkan pengaruh Pemahaman Akuntansi dan Keaktifan Mahasiswa terhadap Penyusunan Laporan Keuangan Sesuai Standar Akuntansi 
Keuangan. Definisi operasional masingmasing variabel adalah sebagai berikut:

1. Pemahaman Akuntansi (X1)

kemampuan merasakan dan memahami secara efektif dalam hal penerapan daya dan kepekaan emosi sebagai sumber energi, informasi, koneksi dan pengaruh yang manusiawi. Pemahaman akuntansi terhadap : (a) Siklus Akuntansi. Menurut Dina Fitria (2014: 28) pengertian Siklus Akuntansi adalah sebagai berikut: "Siklus akuntansi merupakan gambaran tahapan kegiatan akuntansi yang meliputi pencatatan, penggolongan, pengikhtisaran dan pelaporan yang dimulai saat terjadi sebuah transaksi dalam sebuah perusahaan". Sedangkan menurut Rahman Wiratna (2013: 18) pengertian Siklus Akuntansi adalah sebagai berikut: "Siklus akuntansi merupakan serangkaian kegiatan akuntansi yang dilakukan secara sistematika dimulai dari pencatatan akuntansi sampai dengan penutupan pembukuan". Dari beberapa pengertian diatas dapat disimpulkan bahwa siklus akuntansi merupakan serangkaian proses yang menggambarkan tahapan aktivitas atau kegiatan akuntansi secara sistematika dengan melakukan pencatatan, penggolongan, pengikhtisaran dan pelaporan yang dimulai saat terjadi sebuah transaksi dalam sebuah perusahaan. (b)2 Proses Penyusunan laporan keuangan.a. Tahapan- Tahapan dalam Siklus Akuntansi Menurut Hery (2014: 66-67) tahapan-b. tahapan dalam siklus akuntansi dapat3. diurutkan sebagai berikut: (1) Mula-mula dokumen pendukung transaksi dianalisis dan informasi yang terkandung dalam dokumen tersebut dicatat dalam jurnal. (2) Lalu data akuntansi yang ada dalam jurnal diposting ke buku besar. (3) Seluruh saldo akhir yang terdapat pada masing- masing buku besar akun "didaftar" (dipindahkan) ke neraca saldo untuk membuktikan kecocokan antara keseluruhan nilai akun yang bersaldo normal debet dengan keseluruhannilai akun yang bersaldo normal kredit. (4) Menganalisis data penyesuaian dan membuat ayat jurnal penyesuaian. (5) Memposting data jurnla penyesuaian ke masing- masing buku besar akun yang terkait. (6) Dengan menggunakan pilihan (optional) bantuan neraca lajur sebagai kertas kerja (Work sheet), neraca saldo setelah penyesuaian (adjusted trial balance) dan laporan keuangan disiapkan. (7) Membuat ayat jurnal penutup (closing entries).(8) Memposting data jurnal penutup ke masing-masing buku besar akun yang terkait. (9) Menyiapkan neraca saldo setelah penutupan (post closing trial balance). (10) Membuat ayat jurnal pembalik (reversing entries). Untuk perusahaan yang telah memiliki system komputerisasi akuntansi yaitu sebuah perangkat lunak (Software) yang memuat program pemprosesan data dan pelaporan akuntansi, akan secara otomatis memposting jurnal ke buku besar, hingga menghasilkan laporan keuangan dan berbagai laporan lainnya yang dibutuhklan perusahaan, dalam kondisi ini kertas kerja yang sifatnya optional tentu tidak dipergunakan lagi. (c) Penyajian Laporan Keuangan. Penyajian laporan keuangan sesuai Standar Akuntansi Keuangan (SAK) yaitu Laporan Posisi Keuangan , Laporan Laba Rugi, Laporan Perubahan Ekuitas, Laporan Arus Kas dan Catatan Atas Laporan Keuangan.

Keaktifan Mahasiswa (X2)

Keaktifan terhadap problem/kasus akuntansi

. Keaktifan bertanya dan sharing

Penyusunan Laporan keuangan Sesuai Standar Akuntansi Keuangan (Y), indikator mahasiswa memahami penyusunan sampai dengan penyajian laporan keuangan sesuai dengan standar akuntansi keuangan

\section{HASIL DAN PEMBAHASAN Hasil Uji F (Simultan)}

Uji statistik F digunakan untuk mengetahui apakah model yang digunakan dalam regresi telah sesuai. Uji $F$ juga digunakan untuk mengetahui pengaruh semua variabel independen yang dimaksudkan dalam model regresi secara bersama-sama terhadap variabel dependen yang du uji pada tingkat signifikan $F$ lebih rendah dari 
$0,05(5 \%)$. Kriteria pengujian uji $\mathrm{F}$ adalah apabila nilai signifikan $\mathrm{F}$ lebih rendah dari $0,05(5 \%)$, maka dapat disimpulkan bahwa semua variabel independen yang diteliti secara bersama-sama berpengaruh terhadap variabel dependen.

Tabel 1 Uji F

\begin{tabular}{|c|c|c|c|c|c|}
\hline & $\begin{array}{l}\text { Sum of } \\
\text { Squares }\end{array}$ & df & $\begin{array}{l}\text { Mean } \\
\text { Square }\end{array}$ & $\mathrm{F}$ & \\
\hline Regressiom & 2021,67 & 2 & 1010,84 & 57,5 & 0 \\
\hline Residual & 834,66 & 48 & 17,58 & 1 & \\
\hline Total & 2865,33 & 50 & & & \\
\hline
\end{tabular}

Berdasarkan tabel diatas, dapat disimpulkan bahwa nilai signifikan 0,000 berarti nilai sig lebih kecil dari $0,05(0,000$ $<0,05)$. Maka dalam hal ini $\mathrm{H}_{\mathrm{a}}$ diterima dan $\mathrm{H}_{\mathrm{o}}$ ditolak.

\section{Hasil Uji T (Parsial)}

Uji t digunakan untuk mengetahui pengaruh masing-masing variabel bebas (independen) terhadap variabel terikat (dependen) secara parsial. Pengambilan keputusan berdasarkan perbandingan nilai $t$ hitung dan nilai kritis sesuai dengan tingkat signifikan yang digunakan yaitu 0,05 . Pengambilan keputusan didasarkan nilai probabilitas yang didapatkan dari hasil pengolahan data melalui program PSPP.

Tabel 2 .Hasil Uji Regresi

\begin{tabular}{|c|c|c|c|c|c|}
\hline & \multicolumn{2}{|c|}{$\begin{array}{l}\text { Unstandardiz } \\
\text { ed } \\
\text { Coefficients }\end{array}$} & \multirow{2}{*}{$\begin{array}{l}\text { Standardiz } \\
\text { ed } \\
\text { Coefficieb } \\
\text { ts } \\
\text { Beta }\end{array}$} & \multirow[b]{2}{*}{$t$} & \multirow[b]{2}{*}{ Sig } \\
\hline & $B$ & $\begin{array}{l}\text { Std. } \\
\text { Erro } \\
r\end{array}$ & & & \\
\hline $\begin{array}{l}\text { (Consta } \\
n t) \\
\mathrm{X} 1 \\
\mathrm{X} 2\end{array}$ & $\begin{array}{l}10,9 \\
9 \\
, 34 \\
, 44\end{array}$ & $\begin{array}{l}4,96 \\
, 06 \\
, 15\end{array}$ & $\begin{array}{l}, 00 \\
, 58 \\
, 33\end{array}$ & $\begin{array}{l}2,2 \\
2 \\
5,4 \\
0 \\
3,0 \\
2\end{array}$ & $\begin{array}{l}, 03 \\
1 \\
, 00 \\
0 \\
, 00 \\
4\end{array}$ \\
\hline
\end{tabular}

Berdasarkan hasil tabel diatas dapat diketahui bahwa nilai signifikansi variabel Pemahaman Akuntansi (X1) sebesar 0,000 lebih kecil dari 0,05. Sedangkan nilai signifikansi Keaktifan Mahasiswa (X2) sebesar 0,004 lebih kecil dari 0,05. Adapun model persamaan regresi linier berganda adalah sebagai berikut: $\mathrm{Y}=10,99+0,34 \mathrm{X} 1$ $+0,44 \mathrm{X} 2$, dari persamaan regresi diatas diperoleh nilai konstanta sebesar 10,99. Hal ini menunjukan bahwa jika variabel bebas (independen) dalam keadaan tetap, maka
Penyusunan laporan keuangan Sesuai Standar Akuntansi Keuangan yang terjadi sebesar 10,99\%. Nilai koefisien variabel Pemahaman Akuntansi sebesar 0,34, hal ini menunjukan bahwa setiap peningkatan Pemahaman akuntansi akan mengakibatkan pemahaman Penyusunan Sigaporan Keuangan Sesuai Standar .Akuntasi Keuangan akan meningkat 08 besar 3,4\%. Nilai koefisiein variabel Kleaktifan Mahasiswa sebesar 0,44, hal ini menunjukan bahwa setiap ada peningkatan Keaktifan Mahasiswa akan mengakibatkan pemahaman Penyusunan Laporan Keuangan Sesuai Standar Akuntansi Keuangan meningkat sebesar $4,4 \%$.

\section{Hasil Uji Determinasi $\left(\mathbf{R}^{2}\right)$}

Analisis determinasi dalam regresi linear berganda digunakan untuk mengetahui presentase sumbangan pengaruh variabel independen secara serentak terhadap variabel dependen. Adapun hasil analisis koefisien determinasi dalam penelitian ini dapat dilihat pada tabel berikut ini :

Tabel 3 Model Summary

\begin{tabular}{|c|c|c|}
\hline \multirow[b]{2}{*}{ Model R } & \multicolumn{2}{|c|}{ Adjusted $\mathrm{R}$} \\
\hline & R Square Square & Std. Error of the Estimate \\
\hline, $71^{\mathrm{a}}$ & ,50 & 5,77 \\
\hline
\end{tabular}

Dari tabel di atas dapat dilihat bahwa angka $\mathrm{R}$ disebut koefisien korelasi antara variabel Pemahaman Akuntansi dan Keaktifan Mahasiswa terhadap Penyusunan Laporan Keuangan Sesuai Standar Akuntansi adalah 0,50. Ini artinya hubungan antara Pemahaman Akuntansi dan Keaktifan Mahasiswa terhadap Penyusunan Laporan Keuangan Sesuai Standar Akuntansi adalah kuat (signifikan) sebesar $50 \%$. Adjusted R2 dalam penelitian ini 0,50 , hal ini menunjuan bahwa sebesar $50 \%$ pada Penyusunan Laporan Keuangan Sesuai Standar Akuntansi dipengaruhi Pemahaman Akuntansi dan Keaktifan Mahasiswa. Sedangkan sisanya sebesar $50 \%$ dipengaruhi atau dijelaskan oleh faktorfaktor lain yang tidak dimasukkan dalam penelitian ini.

Pengaruh pemahaman akuntansi dan keaktifan mahasiswa secara simultan 
terhadap penyusunan laporan keuangan sesuai standar akuntansi keuangan diperoleh hasil signifikan sebesar 0,000 berarti nilai sig lebih kecil dari $0,05(0,000$ $<0,05)$. Maka dalam hal ini $\mathrm{H}_{\mathrm{a}}$ diterima dan $\mathrm{H}_{\mathrm{o}}$ ditolak yang menunjukkan bahwa Pemahaman Akuntansi dan Keaktifan Mahasiswa secara simultan berpengaruh terhadap Penyusunan Laporan Keuangan Sesuai Standar Akuntansi Keuangan. Kedua variable akan saling mendukung didalam proses penyusunan laporan keuangan yang dikerjakan oleh mahasiswa. Sedangkan pengaruh pemahaman akuntansi secara parsial terhadap penyusunan laporan keuangan sesuai standar akuntansi keuangan menunjukan bahwa secara parsial pemahaman akuntansi sangat berpengaurh signifikan terhadap pemahaman penyusunan laporan keuangan. seorang mahasiswa, jika memahami dari proses pembuatan akun dan no akun, penjurnalan (baik jurnal umum maupun jurnal khusus), input kedalam buku besar (baik double entry maupun buku besar T), pembuatan neraca saldo yang harus seimbang (balance), pembuatan jurnal penyesuaian (akun-akun apa saja yang masuk kedalam jurnal penyesuian), masuk kedalam kertas kerja (worksheet), penyusunan laporan keuangan (dari laba rugi, perubahan modal, neraca, arus kas), pembuatan jurnal penutup (memahami akun apa saja yang masuk kedalam jurnal penutup), jurnal pembalik, paham pembuatan buku pembantu utang dan piutang, stock opname paham pembuatan dan penyusunan laporan keuangan berdasarkan SAK, pasti akan sangat akan lebih mudah dalam penyusunan laporan keuangan. Berdasarkan hasil uji regresi hal ini berarti bahwa mahasiswa Sekolah Tinggi Ilmu Ekonomi Pancasetia Banjarmasin harus paham dahulu dalam penyusunan laporan keuangan terbukti dengan hasil penelitian signifikan sebesar 0,000 lebih kecil dari 0,05 dan paling dominan.

Untuk keaktifan mahasiswa secara parsial terhadap penyusunan laporan keuangan sesuai standar akuntansi keuangan, diperoleh hasil signifikan sebesar 0,004 lebih kecil dari 0,05 dan coefficient beta sebesar 0,33, dengan demikian hipotesis diterima. Keaktifan Mahasiswa dalam proses penyusunan laporan keuangan secara aktif, suka berdiskusi dengan teman sekelompok, aktif bertanya pada dosen yang bersangkutan jika belum memahami, aktif mengemukakan pendapat atas setiap kasus yang diberi oleh dosen, aktif mencari sumber lain dalam menyelesaikan tugas praktikum dan selalu tepat waktu dalam penyelesaian penyusunan laporan keuangan. Berdasarkan hasil penelitian yang telah dilakukan pemahaman akuntansi dan keaktifan mahasiswa secara simultan berpengaruh signifikan terhadap penyusunan laporan keuangan sesuai standar akuntansi dan untuk pemahaman akuntansi dan keaktifan mahasiswa secara parsial berpengaruh signifikan terhadap pemahaman penyusunan laporan keuangan sesuai standar akuntansi. Sedangkan variabel yang dominan berpengaruh signifikan terhadap pemahaman penyusunan laporan keuangan sesuai standar akuntansi keuangan yaitu pemahaman akuntansi. pemahaman akuntansi sebagai dasar pengetahuan dasar akuntansi dalam proses penyusunan laporan keuangan. Sehingga saran yang diberikan kepada objek penelitian diharapkan dapat mengembangkan tingkat pemahaman mahasiswa dengan melakukan pengembangan pembelajaran yang lebih bervariasi dan konsisten khususnya dalam praktik akuntansi, penyelesaian studi kasus yang terkait dengan penyusunan laporan keuangan sesuai standar akuntansi keuangan. Sedangkan bagi mahasiswa agar dapat meningkatkan keaktifan dalam proses pembelajaran seperti aktif bertanya ,megeluarkan pendapat dan sharing pengalaman terkait akuntansi. Serta praktik mandiri dan berpikiran kritis terhadap perkembangan akuntansi di masa akan datang.

\section{REFERENSI}

JIEB Jilid 6, No. 2, Juli 2020 ISSN Online 2615-2134 
Agustina, 2015.Analisis faktor-faktor yang mempengaruhi tingkat pemahaman akuntansi mahasiswa jurusan akuntansi STIE mikroskil medan, Jurnal Wira Ekonomi Mikroskil, Volume 5, Nomor 01, April 2015

Ani Rahmaniar . 2014. Pengantar Akuntansi 1

\section{Us}

Bogor: Penerbit In Media Rusmita, Sari.2012. Analisis Tingkat

Mata Kuliah Dasar-Dasar Akuntansi (Studi pada Mahasiswa AKuntansi-S1 Universitas Islam Negeri Sultan Syarif Kasim Riau). Fokus Ekonomi: Jurnal Ilmiah Ekonomi, Vo. 5, No. 2, Desember 2010 Hal 44-60. Andrey .2013. Akuntansi Keuangan Dasar Pemahaman Mahasiswa Akuntansi Berbasis PSAK . Edisi Pertama,. Jakarta: terhadap KOnsep Dasar Akuntansi Penerbit Mitra Wacana Media.

BH Kusuma, $N$ Bangun.2011.Analisis Bisnis dan Kewairausahaan, Vol. 3, No. 1, Pemahaman Mahasiswa Akuntansi Hal 85-94

Terhdap Konsep Aset, Kewajiban, dSari, Immu Puteri dan Reni Sartika.2018. Ekuitas, Jurnal Bisnis dan Akuntansi,Vol. Pengaruh Perilaku Belajar, Gaya Megajar 13, No.3, Desember 2011, Hal. 183-194

Dina Fitria,2014. Buku Pintar Akuntansi: Untuk Orang Awam \& Pemula Jakarta. Penerbit Laskar Aksara.

Firma. 2019..Analisa Mudah Dengan 2018.

PSPP, Bogor. Penerbit Guepedia Sunyoto, Danang. 2016. Metodologi Penelitian

Kasmir. 2013. Analisis Laporan Keuangan. Edisi Akuntansi. Bandung: PT Refika

Pertama, Cetakan keenam. JakarSuryarini. 2009.Kemampuan Teknis dan Penerbit PT. RajaGrafindo Persada.

Ikatan Akuntansi Indonesia, 2018. Standar Akuntansi Keuangan. Jakarta: PT Salemba Empat

Penalaran Mahasiswa dalam Pengajaran Akuntansi di Perguruan Tinggi. Jurnal Dinamika Akuntansi Vol. 1, No. 1, Maret 2009 Hal 41-50

Kasmir. 2013. Analisis Laporan KeuanganWiratna , 2016. Pengantar Akuntansi. Edisi Edisi Pertama, Cetakan keenam. Jakarta: Penerbit PT. RajaGrafindo Persada.

Mardiyan,R, 2012,Peningkatkan keaktifan dan hasil belajar siswa dalam pembelajaran akuntansi materi jurnal penyesuaian pada siswa kelas xi ips 3 sma ,Negeri 3 bukittinggi dengan metode Bermain peran (role playing).Pakar Pendidikan, Vol 10, No. 2, Juli 2012 Hal 151-162

Mawardi. 2012. Tingkat Pemahaman Mahasiswa Akuntansi Terhadap Konsep Dasar Akuntansi di Perguruan Tinggi Negeri di Kota Malang, Jurnal Ekonomi dan Bisnis Islam, Vol. 8, No. 1.

Melandy, R., F. Widiastuti, dan N. Aziza. 2007. Sinkronisasi komponen kecerdasan emosional dan pengaruhnya terhadap tingkat pemahaman akuntansi dalam sistem pendidikan tinggi akuntansi. Prosiding Simposium Nasional Akuntansi X. Suryaningsum, S., S. Heri

Novius, Andri.2010. Analisis Pemahaman Mahasiswa Akuntansi dalam menhhadapi 